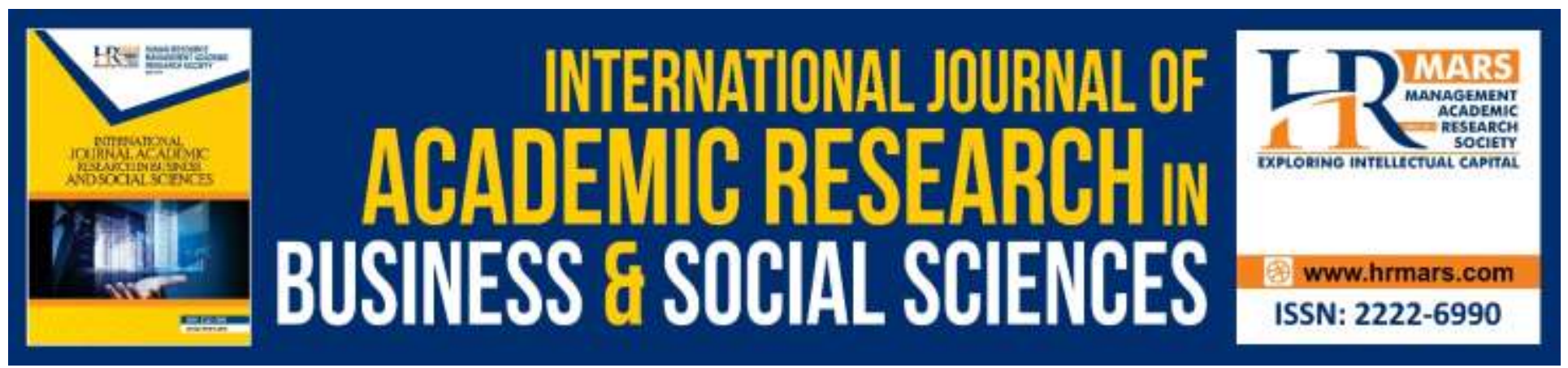

\title{
Human Resource Development Among Administrative Staff at Faculty of Nursing Science, Padjadjaran University (UNPAD) Bandung
}

Nenden Siti Romlah, Sedarmayanti, Sabar Gunawan, Hafid Aditya Pradesa

To Link this Article: http://dx.doi.org/10.6007/IJARBSS/v9-i7/6135

DOI: $10.6007 /$ IJARBSS/v9-i7/6135

Received: 13 May 2019, Revised: 15 June 2019, Accepted: 07 July 2019

Published Online: 27 July 2019

In-Text Citation: (Romlah, Sedarmayanti, Gunawan, \& Pradesa, 2019)

To Cite this Article: Romlah, N. S., Sedarmayanti, Gunawan, S., \& Pradesa, H. A. (2019). Human Resource Development Among Administrative Staff at Faculty of Nursing Science, Padjadjaran University (UNPAD) Bandung. International Journal of Academic Research in Business and Social Sciences, 9(7), 424-436.

Copyright: (C) 2019 The Author(s)

Published by Human Resource Management Academic Research Society (www.hrmars.com)

This article is published under the Creative Commons Attribution (CC BY 4.0) license. Anyone may reproduce, distribute, translate and create derivative works of this article (for both commercial and non-commercial purposes), subject to full attribution to the original publication and authors. The full terms of this license may be seen at: $\underline{\text { http://creativecommons.org/licences/by/4.0/legalcode }}$

Vol. 9, No. 7, 2019, Pg. 424 - 436

http://hrmars.com/index.php/pages/detail/IJARBSS

JOURNAL HOMEPAGE

Full Terms \& Conditions of access and use can be found at http://hrmars.com/index.php/pages/detail/publication-ethics 


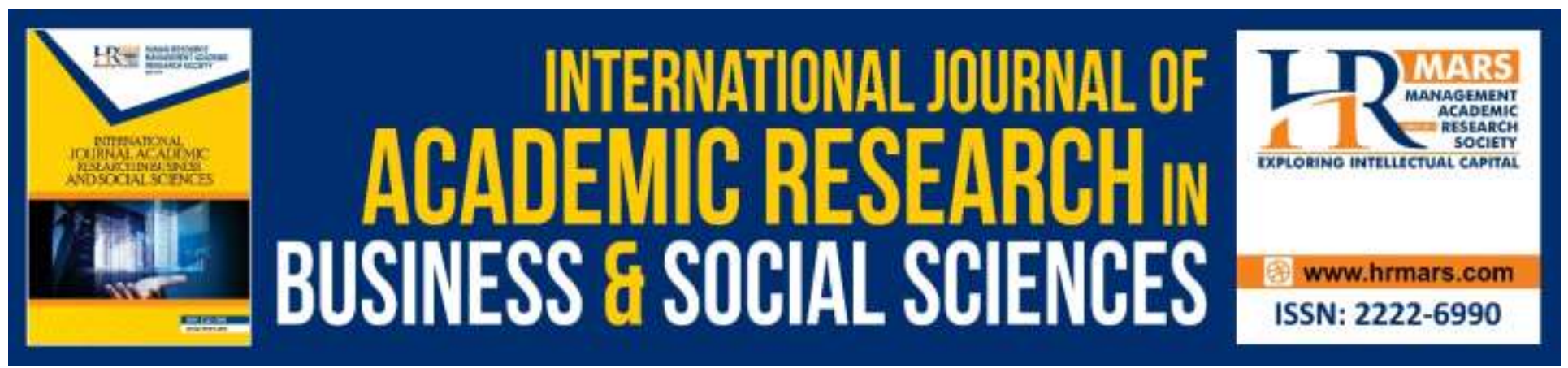

\title{
Human Resource Development Among Administrative Staff at Faculty of Nursing Science, Padjadjaran University (UNPAD) Bandung
}

\author{
Nenden Siti Romlah ${ }^{1}$ Sedarmayanti ${ }^{2}$ Sabar Gunawan ${ }^{3}$, Hafid Aditya \\ Pradesa $^{3}$ \\ ${ }^{1}$ Faculty of Nursing Science, Padjadjaran University (UNPAD) Bandung \\ ${ }^{2}$ Professor, Faculty of Administrative Science - Dr Soetomo University Surabaya - Indonesia and \\ School of Administration, National Agency for State Administration, Bandung, West Java, Indonesia \\ ${ }^{3}$ Lecturer, School of Administration, National Agency for State Administration, Bandung, West Java, \\ Indonesia
}

Abstract: The development of educational administrative personnel has become one of the main concerns in the Faculty of Nursing Science, Padjadjaran University. It aims at improving the competence, professionalism and quality of educational administrative personnel to achieve maximum individual and organizational performance. The purpose of this study is to identify and analyze the implementation of personnel development among administrative personnel, the existing obstacles and efforts or solutions proposed to overcoming the obstacles. The research employed a descriptive qualitative method. The data were collected through observations, interviews and document reviews. The data were then analyzed through the process of data collection, data reduction, data presentation and conclusion drawing. The analysis results showed that in general the implementation of personnel development personnel development among administrative personnelin Padjadjaran University is quite good. Despite of this finding, the aspect of target recognition and the program evaluation were not optimally implemented. It is recommended that the administrative personneldevelopment policies need to be integrated and tailored to the needs of faculty. For this purpose, the training need analysis should be designed. Furthermore, an instrument ought to be formulated for monitoring and evaluation instrument and every educational administrative personnel who has attended a development or training program is required to make a written report.

Keywords: Human Resource Development, Personnel Development, Higher Educational Institution.

Introduction

As Torrington (1988) argued that recruitment, development and management of human resourceis a more sophisticated, human resource development is the individual preparation process to carry out different or higher responsibilities in the organization, usually to improve workability. 
INTERNATIONAL JOURNAL OF ACADEMIC RESEARCH IN BUSINESS AND SOCIAL SCIENCES Vol. 9, No. 7, July, 2019, E-ISSN: 2222-6990 @ 2019 HRMARS

Human resources development for employees is a process of learning and practicing systematically in order to improve their competence and performance in his job and prepare for their roles and future responsibilities. Personnel management has become larger through integrating differ evolutionary underline to make an ever-richer combination of expertise (Torrington, 1988).

From the early 1980's, there has been a large outbreak of research and articles written on the topic about professional development. Each one of them projecting a mixture of separate opinions about just what form professional or personnel development. Thus, the terms staff development, professional development, personnel development, and staff in-service are employed interchangeably in educational literature (Sparks, 2004). Personnel development is a process designed to enable employees to think about, and plan for their own personal and career development in educational institution. Throughout their degree, employees will be advanced to think about their developments and achievements, and to identify areas they wish to improve on. High-quality university-based programs can indirectly increase student performance by enhancing a officers' ability to improve organizational effectiveness. As higher education contribute to develop the foundation for economic advancement for individuals, society, and the world, it is broadly recognized that the successfull University would depends on all staff whatever their role in having the relevant knowledge, skills, and competencies.

The role of administrative staff members has become pivotal in these changing turbulent environments, as for global competition their role is changing regards to broader scope of their office work, so that the competency of administrative staff is a main core factor in organizational effectiveness (e.g. Jung \& Shin, 2015; Volkwein \& Zhou, 2003), and also it could affect indiviudal's behavioral intention (Nawaz, Pangil, \& Bhatti, 2015). Thus, as administrative staff members are fundamental and significant to achieve its success (Chigozie, 2017), and the University would always like to attract and retain high-qualified staff with the competencies necessary to achieve its objectives. Reflecting the changing environments, public organizations including universities have established a human resources section and expanded effective ways of make better of staff members' job competency based on competency models (Jung \& Shin, 2015).

Traditionally, successful organizations depend on the HR function in the administration of officers and job-related services such as recruitment, selection, training, development, rewards and benefits, employee relations, and legal issues. The important role in leveraging employee-related core competencies as a source of competitive advantage still remains as an inspiring goal for many HR departments across organization. A significant value and role for the HR function are few perceived by senior executives regarding to the development of organization members (Alagaraja, 2013; Barney \& Wright, 1998).

The importance of human resource development (HRD) is well established in the previous literature (Clardy, 2008; Ruona, Lynham, \& Chermack, 2003). However, evidence-based study on the adoption process of HRD approaches in spesific organizations is rather quite limited (Alagaraja, 2013a). The contributions of HRD (Human Resource Development) in advancing the linkage to organizational performance and effectiveness are limited but no less significant than HRM contributions. From the standpoint of HRD, connections between structural, cultural, and system characteristics of the organization and their effect on higher levels of performance were central in addressing the HRD-OP (Organizational Performance) linkage. Furthermore, the selection and choice 
of HRD were triggered by required demands of internal and external operating contexts of organization.

From a practical perspective, this research bring new perspective on how the public organization such as public university inherent in strategic human resource management and human resource development practices among teachers and administrators support structural university innovation. From the perspective of human resource management and organizational behavior theory, this research provides an integrated conceptual framework to link structural level and individual level factors to build alignment through strategic human resource development.

\section{HRD in Faculty of Nursing Science UNPAD}

Padjadjaran University (Indonesian: Universitas Padjadjaran, abbreviated as UNPAD) is an one of reputable higher educational institution located in Bandung. Recently in 2019, QS World Universities Ranking, UNPAD is ranked 4th in Indonesia and got in the range of rankings of 651-700th in the world (Wikipedia). In UNPAD, university staff tend to identify and relate themselves as civil servants, rather than as university staff. They always view their career development includes job training with a great priority on a career as a civil servant. Staff development public universitiesis in Indonesia managed as a function of civil servants' career development, although some of reputable universitieshave recently begun to emphasize the personnel development of university staff at the institutional level.

Prior observation that related to the human resources development in the Faculty of Nursing Science UNPAD show that:

1. The development of personnel's knowledge and skills is still not in line with the Faculty Strategic Planning; where the opportunity is to participate in the development program more lecturers rather than education staff. In 2014, $89 \%$ of Lecturers attended training programs, whereas, the education staff was only 30\%; in 2015 50\% of lecturers, and 24\% of staff, and in 2016 about $61 \%$ of lecturers, $24 \%$ of staff, as seen in the following table:

Table 1. Lecturer and Staff development program 2014- 2017

\begin{tabular}{|c|c|c|c|c|c|c|c|c|c|}
\hline \multirow{2}{*}{$\begin{array}{c}\text { Dervelopment } \\
\text { Program }\end{array}$} & \multicolumn{2}{|c|}{2014} & \multicolumn{2}{|c|}{2015} & \multicolumn{2}{|c|}{2016} & \multicolumn{2}{|c|}{2017} & \multirow{2}{*}{ Notes } \\
\hline & 1 & 5 & L & 5 & 1 & 5 & 1 & is & \\
\hline Funther Study & 2 & - & 3 & 1 & 2 & 1 & 1 & 1 & \multirow{6}{*}{ 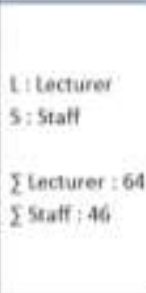 } \\
\hline Training & 16 & 3 & 6 & 7 & 5 & 2 & 9 & $\begin{array}{l}2 \\
1\end{array}$ & \\
\hline Tech Ceuching: & 2 & 9 & 3 & . & 1 & 9 & . & . & \\
\hline $\begin{array}{l}\text { Workstop/ } \\
\text { Seminar }\end{array}$ & $m$ & 2 & 18 & 3 & 27 & . & 25 & 7 & \\
\hline internship & - & $=$ & 2 & - & 4 & . & . & - & \\
\hline Total & 57 & 14 & 32 & 11 & 39 & 11 & 35 & $\begin{array}{l}2 \\
9\end{array}$ & \\
\hline Dercentage (\%) & 199 & 30 & 50 & 24 & 61 & 24 & 54 & $\begin{array}{l}6 \\
3\end{array}$ & \\
\hline
\end{tabular}

Sources: Personnel Division, Faculty of Nursing Science, UNPAD

2. The Development Program has not been carried out optimally so that the faculty still lacks of competent staff in the field of Computer / IT Administration, Archivists, Librarians, Staff Analysts, Finance and public relations, as shown in the table below. 
INTERNATIONAL JOURNAL OF ACADEMIC RESEARCH IN BUSINESS AND SOCIAL SCIENCES

Vol. 9, No. 7, July, 2019, E-ISSN: 2222-6990 @ 2019 HRMARS

Table 2. Competency-based Need of Employees

\begin{tabular}{|c|c|c|c|c|}
\hline No: & Position & $\sum$ Existing & $\sum$ Needed & Notes \\
\hline 1 & Archivist LI & 2 & 4 & \\
\hline 2 & Archivist 12 & 0 & 4 & \\
\hline 3 & Librarian 12 & 1 & 3 & \\
\hline 4 & $\begin{array}{c}\text { Computer } \\
\text { analyst }\end{array}$ & 2 & 4 & $\begin{array}{l}\text { Mulhimedia. Programer: } \\
\text { infrastructure/Web and } \\
\text { it technicians }\end{array}$ \\
\hline 5 & $\begin{array}{l}\text { Personnel } \\
\text { Analyst L1 }\end{array}$ & 1 & 2 & \\
\hline 6 & $\begin{array}{l}\text { Personnei } \\
\text { Analyst } 12\end{array}$ & 0 & 2 & \\
\hline 7 & Finance & 1 & 3 & $\begin{array}{l}\text { Operator, Finance and } \\
\text { Planning }\end{array}$ \\
\hline a & $\begin{array}{l}\text { Public } \\
\text { Relation }\end{array}$ & 0 & 2 & \\
\hline
\end{tabular}

Sources: Personnel Division, Faculty of Nursing Science UNPAD

3. The rapid development of science and technology now demands the quality of human resources who have extensive knowledge and adequate skills. One way to improve is through education. But in terms of academic competence, most of the education staff have high school education, as shown in the following table:

Table 3.Staff Based on Education Level

\begin{tabular}{|c|l|l|c|}
\hline No. & \multicolumn{1}{|c|}{ Level } & \multicolumn{1}{|c|}{ Position/Unit } & Total \\
\hline 1 & Graduate & Manajer & 2 \\
\hline 2 & Undergraduate & $\begin{array}{l}\text { Staff/Academic, Student } \\
\text { Division. }\end{array}$ & 12 \\
\hline 3 & Diploma & $\begin{array}{l}\text { Staff/Academic, Finance } \\
\text { Division. }\end{array}$ & 3 \\
\hline 5 & High School & $\begin{array}{l}\text { Staff/ Personnel,Admin. } \\
\text { Academic Division. }\end{array}$ & 29 \\
\hline & \multicolumn{2}{|r|}{ Total } & 46 \\
\hline
\end{tabular}

Sources: Personnel Division, Faculty of Nursing ScienceUNPAD

\section{Research Question and Contribution}

Clark \& Clark (1991) argued that personnel management (including its development) in organization is thereby reduced to performing a number of peripheral functions whilst increasingly perform its core functions. These issues have arisen from time to time when human resourcemanagement style in organization have pointed out both the importance of a coherent personnel management strategy and its integration into the organization's own policy as a responsibility.

Guided by the theory of how personnel development existed in daily human resource practices, this study specifically aimed to explore personnel development context acts that is described as a key important human resources mechanism in organization. The purpose of this qualitative study is to describe the personel development experiencesof high-quality and reputable university which have successfully created high-performing academic environment for students.

This study contributes to the personnel management literature by addressing the application of personnel development within higher education and highlighting relevant approach. The findings expected to provide insight into ways administrative personnel in higher education could adapt or 
INTERNATIONAL JOURNAL OF ACADEMIC RESEARCH IN BUSINESS AND SOCIAL SCIENCES

Vol. 9, No. 7, July, 2019, E-ISSN: 2222-6990 @ 2019 HRMARS

revise the university's policies and practices to ensure that the organization develops and supports students' college-going aspirations.

\section{Literature Review}

The beginning of personnel management became a central of attention of documented analysis in the 1980s (Thornthwaite, 2012). In that decade, concern in labour process theory pinpoint on many labour historians on the origins and functions of labour management practice. As HRM at the same time rose to colligate and catch personnel management as the specialist occupation focused with managing people in organisations (Weinberger, 1998; Wright, McMahan, \& McWilliams, 1994).

In order to examine the implications of HRM for the personnel function, Torrington (1988) argued the importance of review about how the function has altered and evolved up to the present. Although a spesific ideology could not be ascribed to a perfect group of people at any time, the development of the personnel function can be traced by proposing a usual self-image for personnel that has been assertive at different periods. In birocracy perspective, Torrington (1988) stated that the human bureaucrat was related to get a suitable between a spesific worker and a spesific job.

Sedarmayanti (2017) states that: "Human Resource Management is a process of utilizing HR effectively and efficiently through activities of planning, mobilizing and controlling all values that become human strength to achieve goals". In particular, Noe et.al., 2017) defines: "Human resource development is a planned, continuous effort by management to improve employee competency levels and organizational performance through training, education, and development programs". While Loucks-Horsley \& Sparks, (1998) explained staff development as "those processes that improve the job-related knowledge, skills, or attitudes of school employees..." (p. 41). Spesificaly, they describe staff development as "any process that is intended to or leads to improve student learning through enhanced teacher performance" (p.41). Personnel development would refers to all the procedures, practices, as well as policies in which used to develop the skills, knowledge, and competencies of staff in order to improve both the effectiveness and efficiency of the individual and the University. By providing staff with development opportunities in high educational institution is an urgency to ensure that individuals and departments are able to fully contribute in achieving objectives in the context of the strategic plan.

From the explanation about HR management and development, this would implies to the need of training among employees as important factor in developing their competency (Sedarmayanti, 2013). The training was designed to develop an understanding, a knowledge base, and those skills conducive to administering and managing effective programs for students in university. According to Siagian (2008): "the benefits of training and development could be learned to the maximum extent possible, there are various steps that need to be taken" as follows:

1. Determination of Needs

2. Objective Setting

3. Program Planning

4. Program Implementation

5. Program Evaluation

Based on definitions from the previous educational literature about professional development,the operational definition that will be used in this qualitative research study includes any activity that 
INTERNATIONAL JOURNAL OF ACADEMIC RESEARCH IN BUSINESS AND SOCIAL SCIENCES

Vol. 9, No. 7, July, 2019, E-ISSN: 2222-6990 @ 2019 HRMARS

engages employees in enhancing or improving their skills, knowledge, and disposition thatleads to improving the academic and organizational effectiveness. This definition includes professional development opportunities such as workshops, training, coaching or mentoring, that are designed to improve employees' practice.

\section{Research Framework}

Despite all of the literature that has been written about the steps that must be includedwhen delivering effective outcome based professional development, most school systems still use a more or less traditional model of delivering staff development (Cohen \& Hill, 2000; Joyce \& Showers, 2002; Loucks-Horsley \& Sparks, 1998) .In order to clarify the analysis of human resources development in the Faculty of Nursing Science, it will be seen in the framework scheme described as follows:

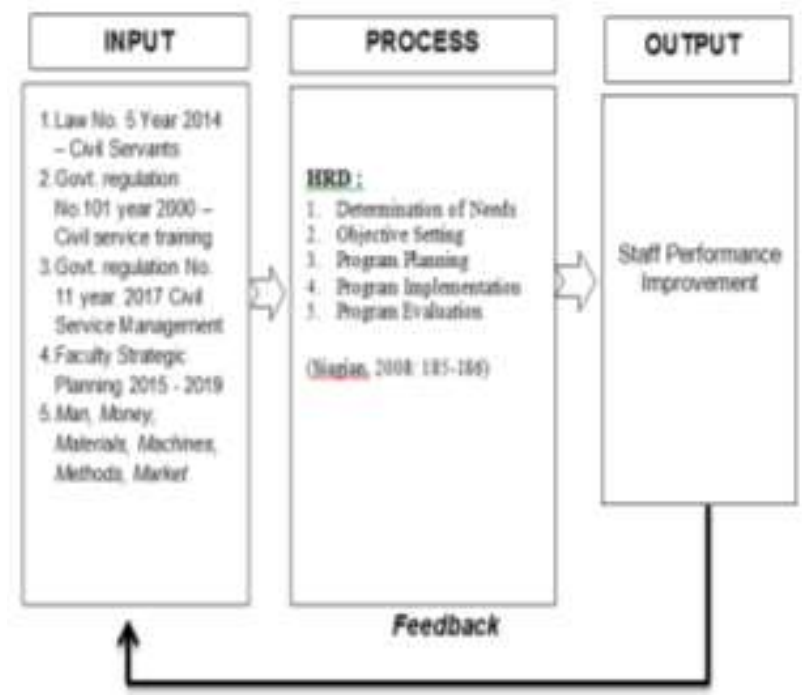

Figure 1.Staff Development Conceptual Model

The conceptual model shown in Figure 1 could be used to analyze the problems identified in this study. The research method used is a qualitative descriptive method. It is a research approach that discusses several possibilities for solving actual problems by collecting data, compiling, clarifying and analyzing. Through this research method, it is expected that the data to be obtained are objective, so the purpose of this study is to find, prove and develop knowledge, so that this research can be used to understand, solve and anticipate problems.

\section{Method}

Since qualitative research starts from assumptions about reality that are unique, complex and multiple, the research activities begin with certain informants (key person) or from certain social situations (Denzin \& Lincoln, 2005). Research informants are people or subjects who will be interviewed or who will be asked for information about research problems (Janesik, 1994). For this reason, those who become research informants are people who are considered to know the most about the object to be studied or the leader as the implementer in this research problem. 
INTERNATIONAL JOURNAL OF ACADEMIC RESEARCH IN BUSINESS AND SOCIAL SCIENCES

Vol. 9, No. 7, July, 2019, E-ISSN: 2222-6990 @ 2019 HRMARS

\section{Result and Discussion \\ Outputs}

Based on a study of documentation in the Faculty of Nursing Science Work Plan for 2016 -2017, it is known that most of the programs and activities carried out by the Faculty must be in the contract of faculty performance signed by the Dean and University Chancellor. The document in 2016 shows some performance indicators related to HR development as follows:

Table 4.Performance Indicator

\begin{tabular}{|c|c|c|}
\hline $\mathrm{KPI}$ & Target & Program \\
\hline Office Service & $80 \%$ & Workshop e-office and SIAT \\
\hline $\begin{array}{c}\text { Performance Improvement of } \\
\text { Human Resources }\end{array}$ & $80 \%$ & $\begin{array}{c}-\quad \text { AMT Training } \\
-\quad \mathrm{T}\end{array}$ \\
\hline $\begin{array}{c}\text { Librarians performance } \\
\text { improvement }\end{array}$ & 2 & $\begin{array}{c}\text { Training program for librarian } \\
\text { or library technicians }\end{array}$ \\
\hline $\begin{array}{c}\text { Performance development of } \\
\text { Human Resources }\end{array}$ & 4 & $\begin{array}{l}\text { Training for administrative, } \\
\text { work flow, and } \\
\text { communication in workplace }\end{array}$ \\
\hline HRD for building maintenance & 2 & $\begin{array}{c}\text { Training program for building } \\
\text { maintenance }\end{array}$ \\
\hline HRD for computer utility & 20 & $\begin{array}{c}\text { Training program for Basic } \\
\text { Computer }\end{array}$ \\
\hline $\begin{array}{l}\text { HRD for laboratory } \\
\text { administrator }\end{array}$ & 7 & $\begin{array}{c}\text { Training program for } \\
\text { Laboratories }\end{array}$ \\
\hline
\end{tabular}

Source : Personnel Division, Faculty of Nursing Science UNPAD

The result that have been described above is sufficient and can be used as a basic guide or guideline to carry out the process of developing staff in the Faculty of Nursing Science UNPAD so that the goals set can be achieved. HR possessed by the faculty and management elements is also an absolute thing because it determines the direction and success of the organization.

\section{Process}

Based on the interview with the key informants (Deputy Dean II and the Planning Manager) related to the evaluation of the program implementation, it is have been argued by them that most of faculty members have not optimally conducted their task. The training program could not increase the employee's performance significantly. It only reaches the quantity or number of programs related to the KPI contract target. However, an evaluation of the implementation of the program has been carried out even though it was not carried out in a structured or systematic manner and was not carried out to all staff who has participated in the training program. In the absence of evaluation and monitoring instruments and observation sheets to get information after completing their training program, the extent of success in staff training programs and the ability to apply the knowledge obtained is difficult to relate to the main tasks and functions in the work unit. 
It reveals that there has not been a specific and comprehensive evaluation of the implementation of the staff development program, thus the results of the training have not been measured such as a review of the problems faced by the staff in the training program. Therefore, the result of the training program is not seen in terms of skills, knowledge and attitudes at work.

\section{Practical Implication}

The findings reveal that good human resource development will support an employee's career planning. Through the education development program at the Faculty, the staff who have completed the Master's Program have held positions as Resource Managers and Planning and Data Managers, who were previously held by the lecturers. In addition to the formation, the requirements for managers must hold Master's Degree in accordance with the field of science, also seen from the competency and experience. With promotions, there is an increase in status and benefits received. Promotion here can also be interpreted as a benchmark of trust in the leadership of education staff and a measure of the success of employees in carrying out their current duties.

The Faculty of Nursing Science needs skilled workers in line with the demands of the development of current institutions. As mentioned above that one of the efforts made by the faculty to improve abilities and skills is through education and training programs. With the training program, it is hoped that staff will be able to work more effectively and efficiently, especially to deal with changes that occur such as changes in technology, work methods, attitudes, behavior, skills and knowledge. The faculty has faced the system changes imposed by the University, which currently manages its database using the Integrated Information System (SIAT) and Oracle. Oracle is a Relational Database Management System that functions to manage information in an open, comprehensive and integrated manner. The database is one component in information technology that is absolutely needed by all organizations that want to have an integrated information system to support organizational activities in order to achieve goals.

However, the Oracle system is still in the development stage, only applied in the fields of finance, goods procurement. The plan for the Oracle system will be implemented in all work units, such as in academic, student affairs and personnel units. So the education and training program is expected to improve employee performance. It can be seen from the process of better work.

The results of interviews with several informants reveal some obstacles related to the program and activities of human resources development, such as lack of motivation, low level of knowledge and creativity of employees.Staff also having lacks of attention, cannot develop ideas or initiatives towards organizational problems, and does not exert effort in achieving organizational goals.

Training program evaluation has not been implemented optimally because there has been no systematic or programmed monitoring and evaluation to follow up on the results of the training so that the level of success of the training and the efficiency of a development program are not clear. Comparison of performance before attending training and after attending training has not been maximally measured.

However, efforts have been taken to overcome those problems as follows:

1. Faculty leaders always try to submit a proposal for a plan to develop the program to the Director of Human Resources by completing proposals as the material for consideration. 
2. Efforts to overcome problems related to low creativity and lack of motivation are to propose to the HR Directorate to guide employees and strive for all staff to be able to participate in training programs or activities in accordance with individual needs and work units. The HR manager also began to develop various development program plans carefully and properly. Another effort is to provide direction and guidance from the Chairperson, especially the Resource Manager, so that they have high motivation, clear goals and are passionate in carrying out their main tasks and functions as employees.

3. The Directorate of Human Resources organizes various training programs for those who have not mastered computers through Microsoft Office Computer Training for beginners and intermediate levels, with Microsoft Word, Excel and Power Point programs as well as other trainings, such as training technical basis that supports the work administration process for civil servant.

\section{Conclusion and Suggestion \\ Conclusion}

In general, the implementation of the development of education staff at the Faculty of Nursing Science has been done well but the evaluation aspect has not been implemented optimally. Some of the steps taken are by determining the needs, setting targets, determining the program, implementing the program and evaluating the implementation of the program, with the following description:

a. The analysis of needs has been done well, it can be seen that there is a process of identifying, directing and designing development programs for education personnel.

b. Setting up targets has not been done properly since there are not adequate personnel who have relevant competencies.

c. In determining the program, the management of the Faculty of Nursing Science has developed a work program by involving relevant parties for the youth development program as outlined in the Terms of Reference.

d. The development program that has been implemented is to include the tendencies of each work unit in various development or training programs, such as seminars, current in-service training. It is more directed at training for certain functional positions such as archivists, librarians, laboratory staff and technical training such as training computer and academic information system training.

e. Although the development program evaluation has been carried out, it has not been implemented optimally because there is still no success rate of education staff, performance improvement or behavior change after training. There is no evaluation monitoring instrument and observation sheet to identify the extent of comparison of physical performance before and after the training. 


\section{Suggestions}

Several suggestions are given as a contribution of thought that can be used for Faculty of Nursing Science in an effort to overcome the obstacles in the implementation of the HR development, as follows:

1. With the policies from the university regarding the development of integrated education personnel, there is a need for coordination between faculty managers in this case the Resource Manager with the HR Directorate to be able to implement the planned development program that is urgent and needed by faculty.

2. In order to be easy in determining the development needs of education staff and not being misdirected and to meet the needs of the faculty for the competence of education personnel in certain fields, it is best to conduct Training Needs Analysis by faculty leaders. The aim is to identify the training needs of each trainee and ensure that all employees attend appropriate training to support their tasks that will affect the quality of work and in accordance with the faculty's strategy.

3. For equal distribution of technical development, it is better to do a re-registration of all employees who have participated in training programs as well as those that are not planning for the implementation of further development programs, for both in-service training and other technical training to achieve the competencies needed to support the implementation of their tasks.

4. A clear procedure should be made for employee competency development.

5. Faculty managers should evaluate activities regularly so that feedback from these activities can be used as a reference for improving minor performance. And the need to make an evaluation monitoring instrument and observation sheet to identify the extent of success in participating in training programs, so that there is an increase in performance or behavior change after training and can be measured both individually and organizationally.

6. Every candidate who has completed a development or training program must be obliged to make a written report on the implementation of activities that have been carried out no later than 1 (one) month after the completion of the activity as evaluation material for the implementation of further activities and can be used as documents or archives of development activities tend faculty. The report submitted contains the name of the activity, time, place, destination, duration of implementation, organizer, resource person, material presented, and benefits obtained by the participants.

\section{Acknowledgment}

The authors would like to express their gratitude to people in Faculty of Nursing Science UNPAD who took part in this study and for their suggestions during the development of this article.

\section{Corresponding Author Nenden Siti Romlah} Faculty of Nursing Science, Padjadjaran University (UNPAD) Bandung

Email: nenden.siti@unpad.ac.id 
INTERNATIONAL JOURNAL OF ACADEMIC RESEARCH IN BUSINESS AND SOCIAL SCIENCES

Vol. 9, No. 7, July, 2019, E-ISSN: 2222-6990 @ 2019 HRMARS

\section{References}

Alagaraja, M. (2013a). HRD and HRM Perspectives on Organizational Performance : A Review of Literature. Human Resource Development Review, 12(2), 117 -143. https://doi.org/10.1177/1534484312450868.

Alagaraja, M. (2013b). Mobilizing organizational alignment through strategic human resource development. Human Resource Development Review, 16(1), 74-93. https://doi.org/10.1080/13678868.2012.740794.

Barney, J. B., \& Wright, P. M. (1998). On becoming a strategic partner: The role of human resources in gaining competitive advantage. Human Resource Management1, 37(1), 31-46. https://doi.org/10.1002/(SICI)1099-050X(199821)37:1<31::AID-HRM4>3.0.CO;2-W.

Chigozie, B. U. (2017). An Assessment of the Impact of Academic Staff Union of Universities ( ASUU ) on Human Resource Development in Nigerian Universities. International Journal of Academic Research in Business and Social Sciences, 7(4), 740-747. https://doi.org/10.6007/IJARBSS/v7$\mathrm{i} 4 / 2866$.

Clardy, A. (2008). The strategic role of Human Resource Development in managing core competencies. Human Resource Development International, 11(2), 183-197. https://doi.org/10.1080/13678860801932998.

Clark, I., \& Clark, T. (1991). Personnel Management: Defence, Retrenchment, Advance? Personnel Review, 20(1), $13-18$.

Cohen, D. K., \& Hill, H. C. (2000). Instructional policy and classroom performance:The mathematics reform in California. Teachers College Record, 102(2), 294-343.

Denzin, N. K., \& Lincoln, T. S. (2005). The SAGE Handbook of Qualitative Research - Third Edition. New York: SAGE Publication Asia Pacific.

Janesik, V. J. (1994). The Dance of Qualitative Research Design Methaphor, Methodolatry, and Meaning. In Handbook of Qualitative Research (pp. 209-219). Thousand Oaks: SAGE Publication.

Joyce, B. R., \& Showers, B. (2002). Student achievement through staff development. Alexandria: VA: Association for Supervision \& Curriculum Development.

Jung, J., \& Shin, J. C. (2015). Administrative staff members' job competency and their job satisfaction in a Korean research university. Studies in Higher Education, 40(5), 881-901.

https://doi.org/10.1080/03075079.2013.865161.

Loucks-Horsley, \& Sparks, D. (1998). Five models of staff development for teachers. Journal of Staff Development, 10(4), 40-57.

Nawaz, M. S., Pangil, F., \& Bhatti, M. A. (2015). The Relationship between Human Resource Development Factors and Turnover Intention : A Conceptual Framework. International Journal of Academic Research in Business and Social Sciences, 5(12), 297-310.

https://doi.org/10.6007/IJARBSS/v5-i12/1959.

Noe, R., Hollenbeck, J., Gerhart, B., \& Wright, P. (2017). Human Resource Management - 10th Edition - Gaining a Competitive Advantage. New York: McGraw Hill.

Ruona, W. E. A., Lynham, S. A., \& Chermack, T. J. (2003). Insights on Emerging Trends and the Future of Human Resource Development. Advances in Developing Human Resources, 5(3), 272-282. https://doi.org/10.1177/1523422303254667.

Sedarmayanti. (2013). Human Resource Development. Yogyakarta: Deepublish. 
INTERNATIONAL JOURNAL OF ACADEMIC RESEARCH IN BUSINESS AND SOCIAL SCIENCES

Vol. 9, No. 7, July, 2019, E-ISSN: 2222-6990 ¿ 2019 HRMARS

Sedarmayanti. (2017). Perencanaan dan Pengembangan Sumber Daya Manusia. Bandung: Refika Aditama.

Siagian, S. P. (2008). Manajemen Sumber Daya Manusia. Jakarta: Bumi Aksara.

Sparks, D. (2004). Focusing staff development on improving the learning of all students. In G. Cawelti (Ed.), Handbook of research on improving student achievement 3rd edition (pp. 245-255). Arlington: VA: Educational Research Service.

Thornthwaite, L. (2012). The origins of personnel management: reasserting the public sector experience. Journal of Management History, 18(3), 312-330.

Torrington, D. (1988). How Does Human Resources Management Change The Personnel Function? Personnel Review, 17(6), 3-9. https://doi.org/10.1108/eb055601.

Volkwein, J. F., \& Zhou, Y. (2003). Testing a model of administrative job satisfaction. Research in Higher Education, 44(2), 149-171.

Weinberger, L. A. (1998). Commonly held theories of human resource development. Human Resource Development International, 1, 75-93. https://doi.org/10.1080/13678869800000009.

Wright, P. M., McMahan, G. C., \& McWilliams, A. (1994). Human resources and sustained competitive advantage: A resource-based perspective. International Journal of Human Resources Management, 5, 301-326. https://doi.org/10.1080/09585199400000020. 